Article

\title{
Engineering of Janus-Like Dendrimers with Peptides Derived from Glycoproteins of Herpes Simplex Virus Type 1: Toward a Versatile and Novel Antiviral Platform
}

\author{
Annarita Falanga ${ }^{1}\left(\mathbb{D}\right.$, Valentina Del Genio ${ }^{2}(\mathbb{D})$, Elizabeth A. Kaufman ${ }^{3}$, Carla Zannella ${ }^{4}$, Gianluigi Franci ${ }^{5}{ }^{(D)}$ \\ Marcus Weck $^{3}$ (D) and Stefania Galdiero ${ }^{2, *}$ (D)
}

1 Department of Agricultural Sciences, University of Naples "Federico II", Via Università 100, Portici, 80055 Naples, Italy; annarita.falanga@unina.it

2 Department of Pharmacy and CIRPEB, University of Naples "Federico II", Via Montesano 49, 80131 Naples, Italy; valentina.delgenio@unina.it

3 Department of Chemistry and Molecular Design Institute, New York University, New York, NY 10003, USA; eak393@nyu.edu (E.A.K.); mw125@nyu.edu (M.W.)

4 Department of Experimental Medicine, Second University of Naples, Via de Crecchio 7, 80138 Naples, Italy; carlazannella88@gmail.com

5 Department of Medicine, Surgery and Dentistry "Scuola Medica Salernitana", University of Salerno, 84081 Baronissi, Italy; gfranci@unisa.it

* Correspondence: stefania.galdiero@unina.it

Citation: Falanga, A.; Del Genio, V.; Kaufman, E.A.; Zannella, C.; Franci, G.; Weck, M.; Galdiero, S.

Engineering of Janus-Like Dendrimers with Peptides Derived from Glycoproteins of Herpes Simplex Virus Type 1: Toward a Versatile and Novel Antiviral Platform. Int. J. Mol. Sci. 2021, 22, 6488. https://doi.org/10.3390/ ijms22126488

Academic Editor: Istvan Simon

Received: 25 May 2021

Accepted: 11 June 2021

Published: 17 June 2021

Publisher's Note: MDPI stays neutral with regard to jurisdictional claims in published maps and institutional affiliations.

Copyright: (C) 2021 by the authors Licensee MDPI, Basel, Switzerland. This article is an open access article distributed under the terms and conditions of the Creative Commons Attribution (CC BY) license (https:/ / creativecommons.org/licenses/by/ $4.0 /)$.

\begin{abstract}
Novel antiviral nanotherapeutics, which may inactivate the virus and block it from entering host cells, represent an important challenge to face viral global health emergencies around the world. Using a combination of bioorthogonal copper-catalyzed 1,3-dipolar alkyne/azide cycloaddition (CuAAC) and photoinitiated thiol-ene coupling, monofunctional and bifunctional peptidodendrimer conjugates were obtained. The conjugates are biocompatible and demonstrate no toxicity to cells at biologically relevant concentrations. Furthermore, the orthogonal addition of multiple copies of two different antiviral peptides on the surface of a single dendrimer allowed the resulting bioconjugates to inhibit Herpes simplex virus type 1 at both the early and the late stages of the infection process. The presented work builds on further improving this attractive design to obtain a new class of therapeutics.
\end{abstract}

Keywords: antiviral compounds; dendrimers; peptides

\section{Introduction}

Outbreaks and pandemic transmission of viruses, such as coronaviruses and influenza viruses, set off a global health emergency across the world. The recent COVID-19 pandemic has demonstrated its catastrophic impact worldwide on human health and on socioeconomic growth [1]. A major challenge against infections triggered by many viruses is the lack of effective methods for prevention and treatment. Nanotechnology provides the foundation for the advancements in antiviral strategies [2]. In fact, several unique features of nanomaterials (such as small-size, high surface-to-volume ratio modifiable surfaces) may contribute to favor multiple antiviral effects, which may include virus inactivation and blocking a virus from entering host cells.

Synthetic polymer scaffolds have played a primary function in the progress of modern biomedicine. Not only have macromolecules exhibited antimicrobial, antifouling, and stimuli-responsive properties [3-5], there are prominent examples of biocompatible, yet fully synthetic, systems that function in drug delivery, tissue engineering [6,7], and the fabrication of bone growth scaffolds [8,9]. The development of controlled polymerization routes such as ring-opening polymerization [6,10-12], ring-opening metathesis polymerization [13], and controlled radical polymerization methods [14-17] has allowed for the 
synthesis of well-defined and multifunctional scaffolds. Multiple polymer systems such as poly(lactide) [18-21], poly(norbornene) [22,23], and poly(benzyl-L-glutamate) [24-26] have been exploited to engineer functional architectures such as polymer-protein conjugates [27-33], polymer vesicles [34-38], drug delivery scaffolds [26,34,39], and organic nanoparticles [40].

Dendrimers are a discrete and sequence-specific platform capable of securing multiple orthogonally bound functionalities (e.g., dyes, peptides, drugs) within a well-defined and tailored arrangement. Dendrimers, products of an iterative synthesis with discrete monomer building blocks, are functional nano/macromolecules owing to a well-defined size, tailored structure, and precise number of active termini that dictate their properties and applications [41]. While groundbreaking work on dendrimers was accomplished over 30 years ago, dendrimers [42-45] appear to be one of the most attractive synthetic architectures for many disciplines with the most effective applications ranging from transdermal drug delivery [46], gene delivery [47], and as magnetic resonance imaging contrast agents [48], to dendritic sensors and safe and effective microbicides [49,50]. Dendrimers represent one of the most promising drug delivery scaffolds (DDS) [51] for targeted drug delivery.

Dendrimers are monodisperse with a perfectly branched architecture [52,53]. As they grow in generation, the number of termini exponentially increases, while only linearly increasing in radius. Thus, the termini become more densely packed, giving the entire structure a globular shape wherein the termini radiate outwards from a central core. Monodispersity and globularity along with multivalency, self-assembling capacity, electrostatic interactions, chemical stability, low cytotoxicity, and aqueous solubility are all features that continually reveal dendrimers to be a prominent choice in the biomedical field [54]. Dendrimers appear to be also an appropriate carrier for the delivery of antiviral therapeutics thanks to their controllable release potency and improved translocation across epithelial and endothelial barriers; moreover, the presence of multiple peripheral functional groups facilitates a higher binding affinity towards surface viral proteins.

Herein, we report the synthesis of two functional Newkome-type dendrimer scaffolds, comprised of monotelechelic and heterotelechelic termini that are engineered for postsynthetic bioconjugation of selected peptides. We exploit the valency of the resulting monofunctional and Janus-type architectures to anchor antiviral peptide sequences derived from the envelope fusion-glycoproteins ( $\mathrm{gH}$ and $\mathrm{gB}$ ) of Herpes simplex virus type 1 (HSV-1). HSV represents one of the major global health problems; over the past 40 years, numerous strategies have been developed to fight the herpetic infection and three classes of drugs are licensed for HSV treatment, all based on the inhibition of viral DNA replication such as acyclovir (ACV), cidofovir, and foscarnet [55]. Although these agents are efficacious against the HSV infection, side effects and limitations are associated with their use. Importantly, the resistance, especially among immunocompromised patients undergoing long-term therapy, represents an important clinical problem [56]. Therefore, it is of utmost importance to identify alternative antiviral systems with different mechanisms of action and different targets [57].

The emergence of virus-derived peptides as new antiviral agents has strongly impacted anti-HSV research. Peptides have several advantages; indeed, they can be both highly specific and effective, while their inherent biodegradability limits their overall accumulation in tissues, resulting in lower toxicity. Although several drawbacks are associated to their use such as short half-life, potential immunogenicity [58], and high production costs, the design of peptidomimetics can overcome these issues. This work proposes the combination of dendrimer and peptide chemistry into the formation of a new biomedical scaffold able to combat HSV with different mechanisms during the infection process.

HSV-1 enters cells through fusion of the viral envelope with the plasmatic membrane of the host cell in a flow of molecular interactions involving multiple viral glycoproteins and cellular receptors [59]. The envelope glycoproteins $\mathrm{gH} / \mathrm{gL}, \mathrm{gB}$, and $\mathrm{gD}$ are all essential for the entry process, and the four glycoproteins are able to induce the fusion of cellular membranes in the absence of virus infection [60]. The present paradigm of entry foresees 
gD-receptor binding/signalling $\mathrm{gH} / \mathrm{gL}$ to trigger $\mathrm{gB}$ to mediate fusion. The trimeric fusion protein $\mathrm{gB}$ inserts into the host cell membrane and refolds to fuse the viral and cellular membranes, allowing the viral capsid and genome to enter the host cell [61]. Prior to receptor binding, the $\mathrm{C}$-terminus of the $\mathrm{gD}$ ectodomain occludes the receptor-binding site. $\mathrm{gD}$ receptor binding displaces the $\mathrm{gDC}$-terminus and transmits a signal to activate $\mathrm{gH} / \mathrm{gL}$, which then transmit this signal to trigger the fusion protein $\mathrm{gB}$. Eventually, $\mathrm{gB}$ inserts its fusion loops into the host cell membrane and collapses back on itself, thereby fusing the viral and cell membranes [61,62]. Likely, more than one gB trimer must be triggered to create a fusion pore, which allows the viral capsid to enter the cell.

Peptides interfering with any of these steps influence viral penetration and may present a considerable inhibitory activity with low toxicity. As a matter of fact, we previously reported the antiviral activity of several peptides derived from glycoproteins $\mathrm{gH}$ and $\mathrm{gB}$, which may interfere with the many conformational changes of these glycoproteins, ending in viral penetration [63-67]. We analysed the antiviral activities of the peptide gH493-511 and its longer version gH493-537 [65]. Results showed a higher activity of the shorter sequence $\left(\mathrm{IC}_{50}=160 \mathrm{mM}\right)$ and an ability to inhibit infectivity when present during virus attachment-entry into cells; in fact, no activity was observed when cells were infected with HSV-1 for $45 \mathrm{~min}$ and only afterwards the peptide was added to the inoculum and in cell-preexposure experiments. A scrambled version did not inhibit HSV-1 infectivity under analogous experimental conditions and the peptide was shown to be specific as no activity was revealed with unrelated enveloped viruses such as parainfluenza-2 virus [65]. Furthermore, with the purpose of interfering with conformational changes, we previously developed a set of peptides designed on the amino acid sequence of the long helical region present in the post-fusogen structure of $\mathrm{gB}$ and we developed some peptide sequences that were highly effective in inhibiting the virus thanks to their ability to trap gB in its pre-fusogenic state and impede the refolding process from pre- to post-fusion state $[62,67]$. These data make gB peptide analogues attractive candidates for further drug development against HSV-1 and, analogously to other viruses, we also demonstrated that membrane targeting through cholesterol conjugation significantly enhanced the antiviral potency of our prototype inhibitors [68].

Nonetheless, antiviral peptide activity relies on a reversible binding event, which may reduce their usefulness in vivo. In fact, in vivo dilution causes a loss of binding and the release of an unaltered virus particle, which is again infective. Recently, it was reported that strong multivalent binding [69] may head to local distortion and consequent virus deformation, which cause irreversible loss of infectivity. We explored the likelihood to produce an irreversible deformation of viral particles through the multivalency of dendrimers and the use of two different peptide sequences (one derived from $\mathrm{gH}$ and the other from $\mathrm{gB}$ ) with different targeting and inhibition mechanisms.

\section{Results and Discussion}

\subsection{Synthesis of DendrimerA and DendrimerB}

Our dendrimer design is based on the Newkome-style dendrimers that are polyamidebased, thus mimicking proteins, assuring biocompatibility, and promoting biodegradability. We have previously reported the syntheses of both the monofunctional dendrimer scaffold (DendrimerA) and the Janus-type dendrimer (DendrimerB) (Figure 1) [70,71] (see also SI with synthetic and purification details of the Janus dendrimer). 
A

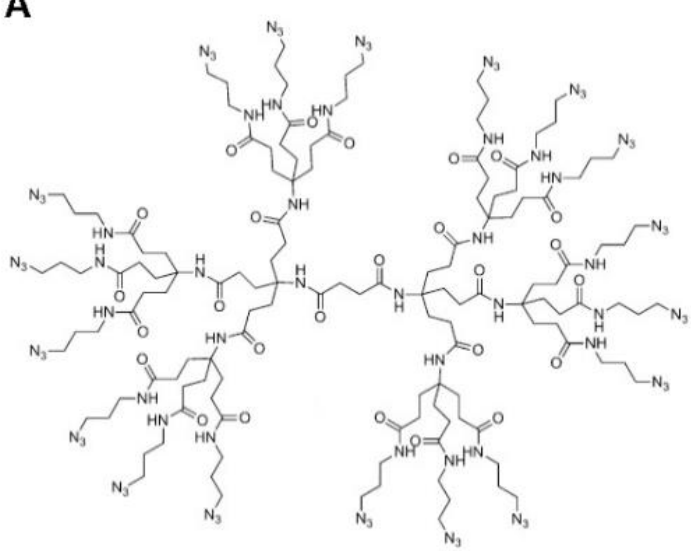

B

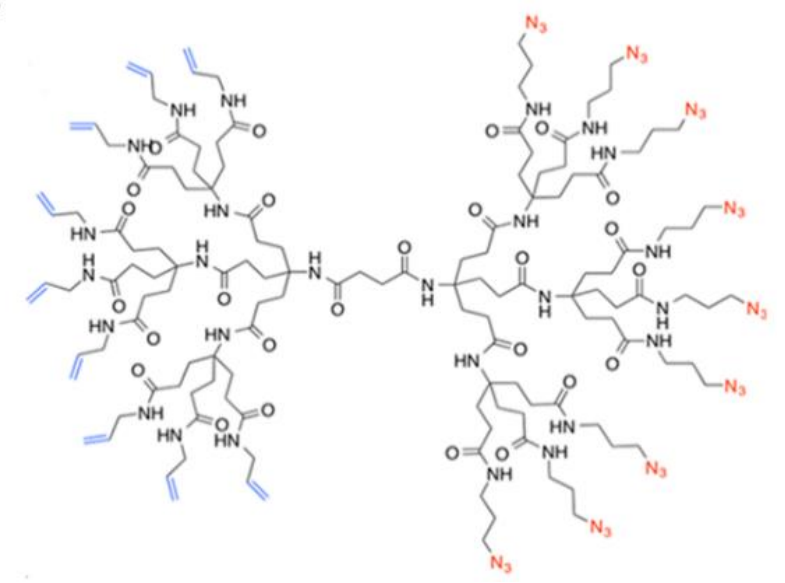

Figure 1. DendrimerA (panel A) and Janus-type DendrimerB (panel B) used in the study.

\subsection{Peptide Functionalization of Monofunctional (DendrimerA) and Janus (DendrimerB) Dendrimers}

The two peptides (see Table 1 for sequences) were bound to the dendrimer differently. The $\mathrm{gB}$ peptide was coupled from the $\mathrm{C}$-terminus. A preliminary antiviral analysis performed on the $\mathrm{gB}$ peptide linked to the dendrimer from the $\mathrm{N}$-terminus and the $\mathrm{C}$-terminus confirmed previous results showing that the peptide loses activity when bound from the $\mathrm{N}$-terminus (data not shown). A similar result was also reported by Lombardi et al. [68], indicating that cholesterol tagging was more effective when the C-terminus of the peptide was modified. As for the $\mathrm{gH}$ peptide, we evidenced an opposite result with slightly better results when functionalizing the $\mathrm{N}$-terminus (data not shown). For this reason, we decided to bind the $\mathrm{gB}$ peptide from the $\mathrm{C}$-terminus and the $\mathrm{gH}$ peptide from the $\mathrm{N}$-terminus.

Table 1. Peptide Sequences and dendrimer used.

\begin{tabular}{ccccc}
\hline Compounds & Peptide & Sequence & MW & Charge \\
\hline gH & PrA-gH493-511 & NH $_{2}$-PrA-AAHLIDALYAEFLGGRVLT-CONH & 2 & 2124 \\
Cys-gH & Cys-gH493-511 & Ac-C-AAHLIDALYAEFLGGRVLT-CONH & -1 \\
gB & gB503-523-PrA & NH $_{2}$ - FARLQFTYNHIQRHVRDMEGR-PrA-CONH & 2 \\
DendrimerA & & Monofunctional dendrimer & 2769 & -1 \\
DendrimerB & & Bifunctional dendrimer & 3430 & +2 \\
\hline
\end{tabular}

The peptides were synthesized with a propargyl glycine residue (PrA) at the correct terminus to provide a handle for the copper-catalyzed azide/alkyne cycloaddition reaction (CuAAC) with the terminal azides of DendrimerA. The click functionalization was performed in a water/methanol solution $(1: 1 \mathrm{v} / \mathrm{v})$ with 2:4 equivalents of $\mathrm{CuSO}_{4} \cdot 5$ $\mathrm{H}_{2} \mathrm{O}$ :sodium ascorbate. The conjugates were extensively purified through dialysis, HPLC, and ultrafiltration on $30 \mathrm{KDa}$ filters.

Successful peptide conjugation was confirmed using HPLC through the appearance of new peaks at retention times (RT) different from the controls that were run at the same conditions (Figure 2, panels A and B). The peptide coupling was also confirmed by IR spectroscopic analysis demonstrating the disappearance of the azide stretch at $2098 \mathrm{~cm}^{-1}$ suggesting that, within the instrumental error range, azides were consumed and converted in triazoles (Figure 2, panels C and D). 

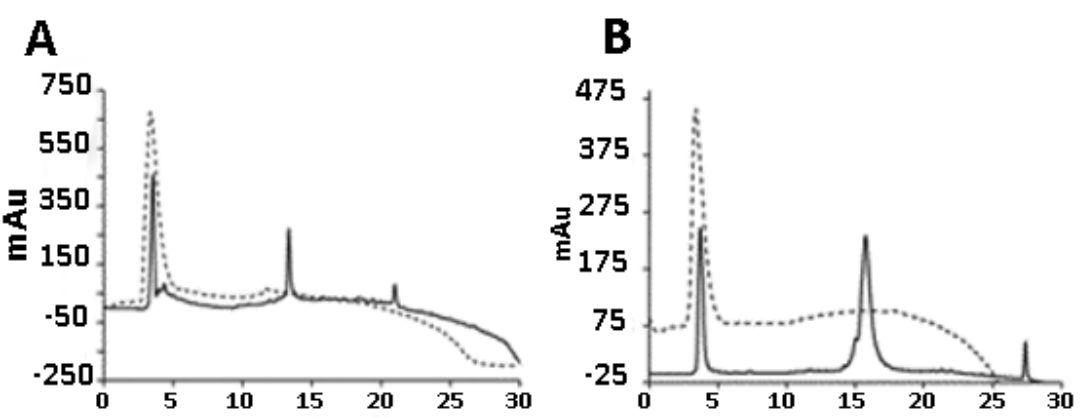

C

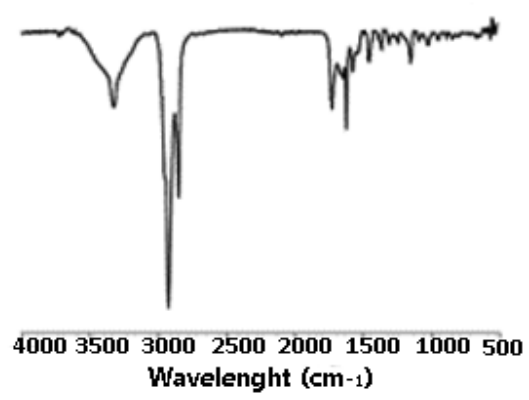

D

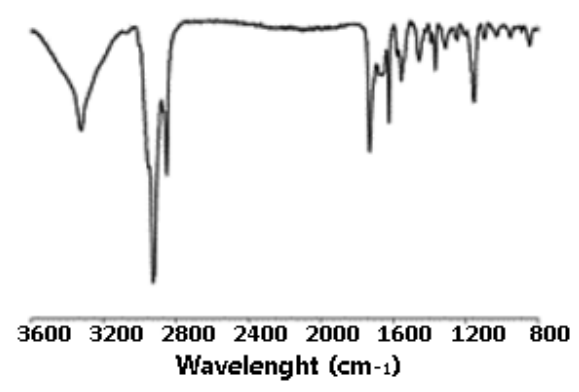

Figure 2. HPLC traces of crude (solid line) and purified (dashed line) peptidodendrimer conjugates, DendrimerA-gH (panel A), DendrimerA-gB (panel B). IR spectroscopic analysis of DendrimerA-gH (panel C) and DendrimerA-gB (panel D).

DendrimerB was functionalized with Cys-gH via photoinduced thiol-ene reaction and with gB-Pra via copper-catalyzed azide/alkyne cycloaddition. The thiol-ene reaction was performed with the Cys-gH peptide in DMF- $\mathrm{H}_{2} \mathrm{O}$ in presence of DMPA at $4{ }^{\circ} \mathrm{C}$ for $1 \mathrm{~h}$ with UV light irradiation. Subsequently, DendrimerB/gH was functionalized with $\mathrm{gB}$ as reported above. The conjugates were purified through dialysis and analysed by IR spectroscopy and $\zeta$-potential measurements. IR analysis demonstrated the disappearance of the azide stretch, suggesting that $\mathrm{gB}$ was conjugated to DendrimerB and the reduction of the stretching $\mathrm{C}=\mathrm{C}$ at $1633 \mathrm{~cm}^{-1}$ indicating the formation of the bond between Cys-gH and DendrimerB. Furthermore, analysis of the zeta-potential results show that a negative charge was obtained for DendrimerB $(-11 \mathrm{mV})$, while a positive charge was obtained for DendrimerB $+\mathrm{gB} / \mathrm{gH}(+5.17 \mathrm{mV})$ (Table 2$)$. The net $\zeta$-potential value, observed at $\mathrm{pH} 7$, further supports peptide conjugation on the dendrimer surface.

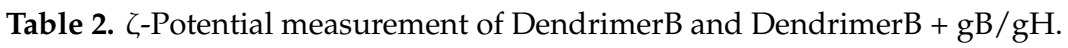

\begin{tabular}{ccc}
\hline & $\zeta$-Potential $(\mathrm{mV})$ & Std. Dev $(\mathrm{mV})$ \\
\hline DendrimerB & -11.0 & \pm 1.6 \\
DendrimerB $+\mathrm{gB} / \mathrm{gH}$ & 5.17 & \pm 0.27 \\
\hline
\end{tabular}

\subsection{Circular Dichroism}

The molecular conformation of DendrimerB $+\mathrm{gB} / \mathrm{gH}$ was investigated by far- $\mathrm{UV} \mathrm{CD}$ spectroscopy, which is an excellent technique for rapid determination of the secondary structure (Figure $3 \mathrm{~A}$ ). As expected, the $\mathrm{CD}$ spectrum in water indicated a random coil conformation for DendrimerB $+\mathrm{gB} / \mathrm{gH}$ (Figure $3 \mathrm{~A}$ ). Both peptides $\mathrm{gH}$ and $\mathrm{gB}$ are random coil in aqueous solution but form an $\alpha$ helix in membrane-mimetic environments $[62,65,72]$. CD spectra were obtained in several percentages of trifluoroethanol (TFE), which is widely used to simulate the membrane environment. The spectrum of DendrimerB $+\mathrm{gB} / \mathrm{gH}$ show that the peptides adopt an $\alpha$ helix with minima at approximately 208 and $222 \mathrm{~nm}$. 
(Figure 3A). The obtained spectra suggest that the secondary structure of the peptides was not disturbed by attachment to a dendrimer.
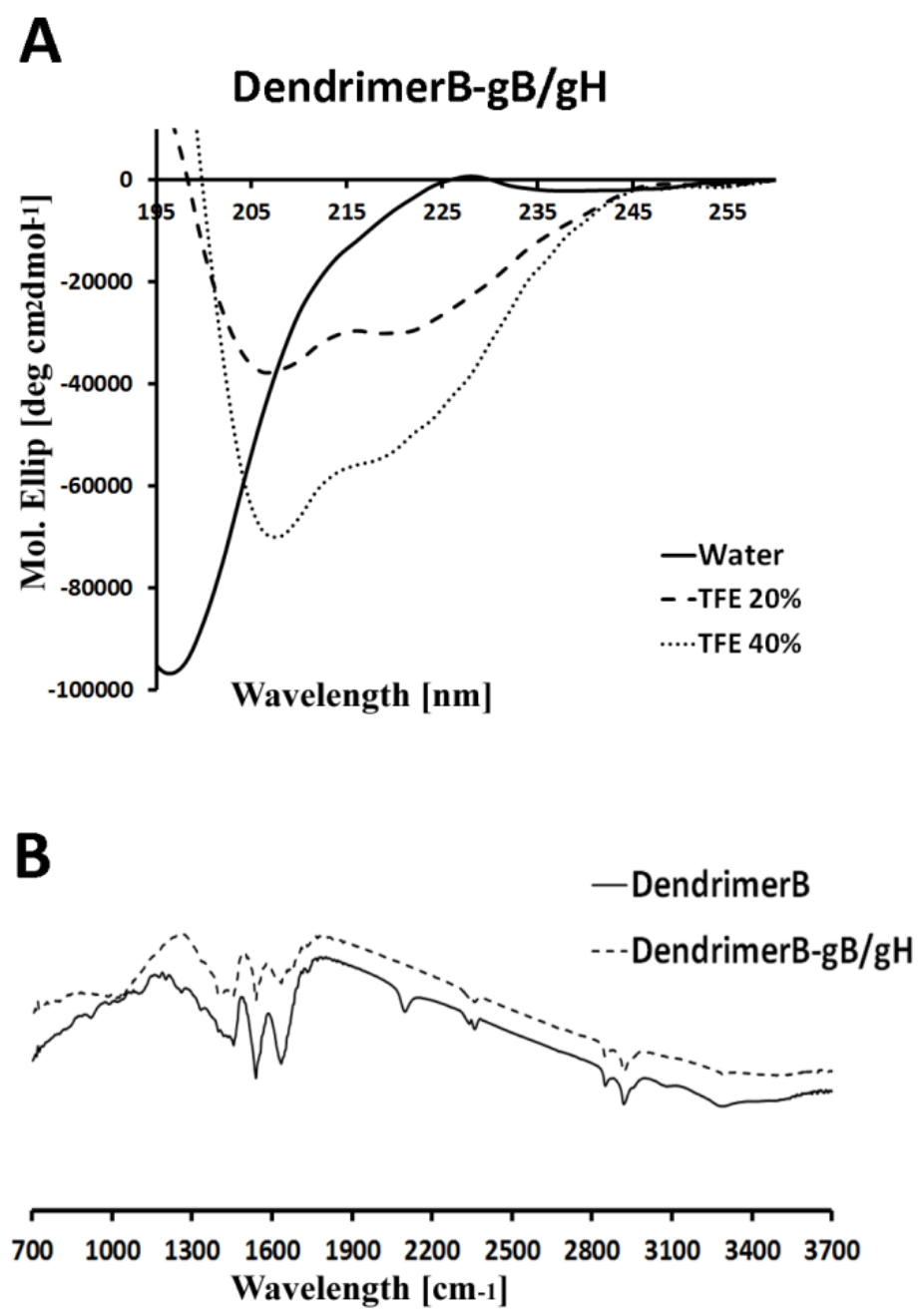

Figure 3. Circular dichroism of DendrimerB $+\mathrm{gB} / \mathrm{gH}$ in water with different percentage of TFE (panel A) and IR spectroscopic analysis of DendrimerB and DendrimerB $+\mathrm{gB} / \mathrm{gH}$ (panel B).

\subsection{Cytotoxicity Studies}

To confirm that synthetized peptide dendrimers do not cause toxic effects on cells, monolayers of Vero cells were exposed to different concentrations $(5.5 \mathrm{nM}, 55 \mathrm{nM}, 0.28 \mu \mathrm{M}$, $0.55 \mu \mathrm{M}, 1.1 \mu \mathrm{M}, 2.8 \mu \mathrm{M}$ ) of each compound for 3, 24 and $48 \mathrm{~h}$, and cell viability was determined by the MTT assay. No statistical difference was detected between the viability of control (untreated) cells and that of cells exposed to the peptide dendrimers (Figure 4) up to the concentration used in antiviral testing at 3 and $24 \mathrm{~h}$. A small decrease in viability was observed at $48 \mathrm{~h}$. Marginal toxicity was obtained for the dendrimer without the peptides linked to its termini, at concentrations that were considerably higher than those required for antiviral activity. 

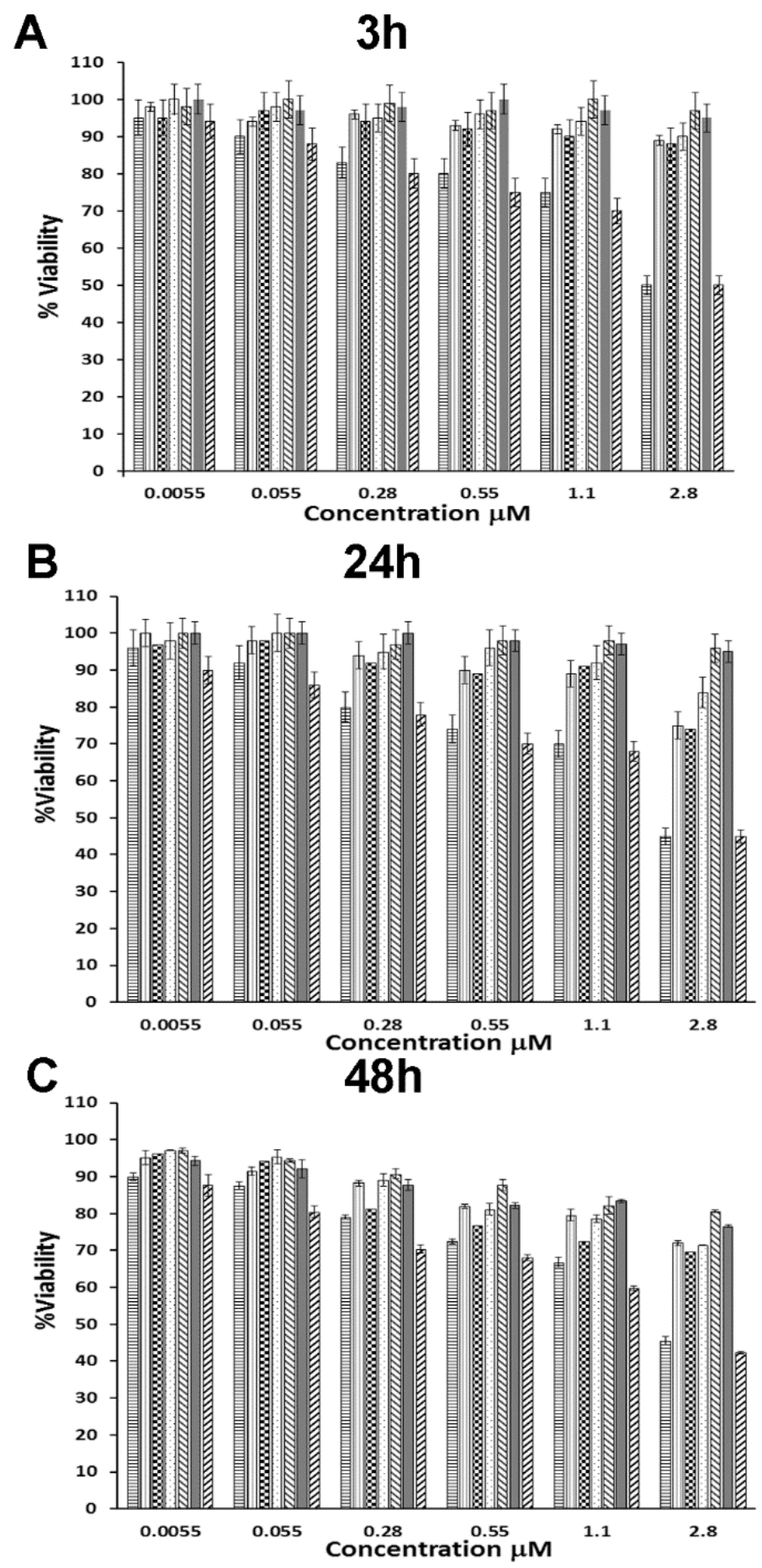

\begin{tabular}{|ll|}
\hline 目DendrimerA & $\square$ DendrimerA-gB \\
DendrimerA-gH & $\square$ DendrimerB-gB/gH \\
$\mathbb{Q g B}$ & $\square \mathrm{gH}$ \\
$\square$ DendrimerB & \\
\hline
\end{tabular}

Figure 4. Cytotoxicity experiments performed after $3 \mathrm{~h}$ (panel A), after $24 \mathrm{~h}$ (panel B) and after $48 \mathrm{~h}$ (panel C). Experiments were performed in triplicate, and the percentages of viability were calculated with respect to no-compound control experiments. Error bars represent standard deviations. 


\subsection{Antiviral Assays}

To test whether the peptide dendrimers are able to inhibit HSV-1 in vitro, several experiments were performed. A virus yield reduction assay in which the peptide dendrimers of interest were present in the cell culture during and after viral adsorption was initially performed. The degree of HSV-1 replication was determined by titration of harvested viruses, and showed a consistent decrease in replication efficiency with more than $60 \%$ inhibition at a peptide-dendrimer concentration of $5.5 \mathrm{nM}$ for both DendrimerA-gB and DendrimerB $+\mathrm{gB} / \mathrm{gH}$, while we observed the same percentage of inhibition for DendrimerA-gH only at $550 \mathrm{nM}$. Inhibition of HSV-1 replication with the Janus bifunctionalized dendrimer was able to reach $90 \%$ already at $55 \mathrm{nM}$. DendrimerA, without any peptide conjugation, was able to produce an inhibition close to $30 \%$ at the highest concentration used (550 nM), suggesting that the dendrimer structure itself grants a certain level of antiviral activity, which is strongly enhanced by the specific peptide sequence coupled to its termini (Figure 5, panel A).
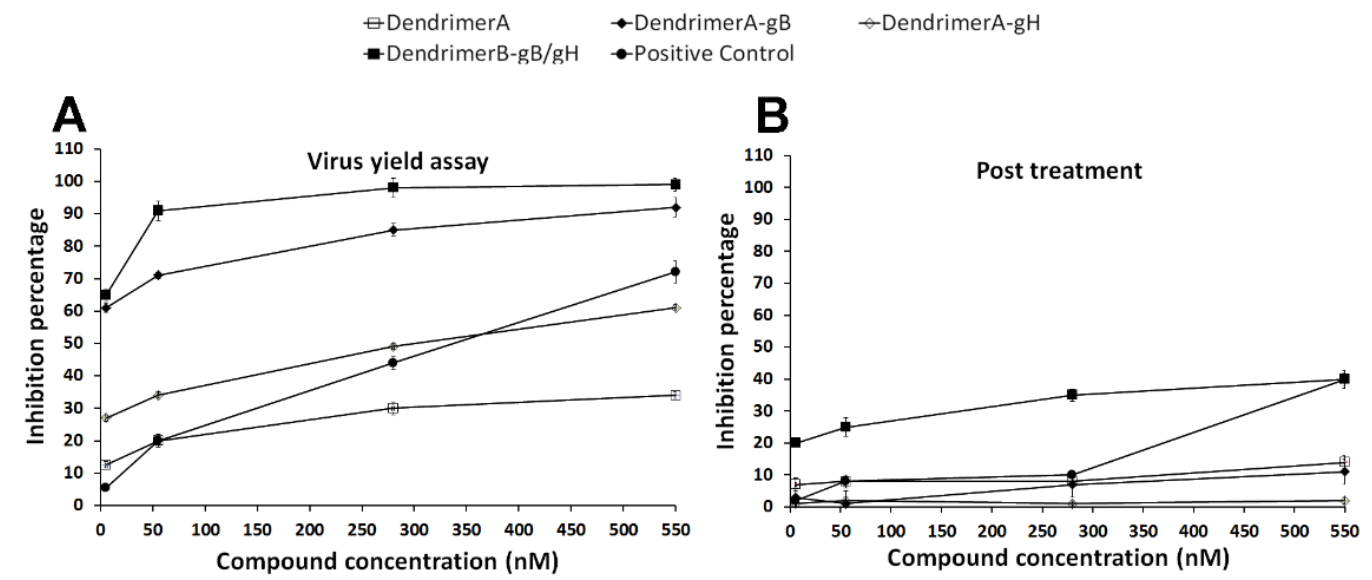

Figure 5. (A) Compounds were present in the cell culture during and after viral adsorption (virus yield assay); (B) cells were exposed to compounds after virus penetration (post treatment). The control used in both experiments is acyclovir. Experiments were performed in triplicate, and the percentages of inhibition were calculated with respect to no-compound control experiments. Error bars represent standard deviations.

In order to identify the step in the entry process that was being inhibited by our compounds, and thus to understand the mechanism of inhibition, the compounds were tested under different conditions. Our hypothesis was that the Janus dendrimer was able to interfere during the early penetration phase. To exclude the hypothesis of an action inside the cell at a post-entry event, a post-treatment assay was executed by adding the compounds at different concentrations (Figure 5, panel B). No concentrations used in this experiment were able to significantly reduce HSV-1 replication, indicating that both the dendrimer and the peptide dendrimers were ineffective once the viruses had already entered inside the cell. The results described soundly suggest that our compounds target an early step of the HSV infection cycle. Some low activity was observed for the Janus dendrimer (DendrimerB $+\mathrm{gB} / \mathrm{gH}$ ), indicating that the bifunctionalized dendrimer may have access in the cell interior, and thus, also exert its function inside the cell.

In addition, other experiments were performed to better clarify the mechanism of infection. As shown in Figure 6, panel A, a significant inhibitory effect was observed when the virus was incubated with compounds and subsequently added to the cells. The highest inhibition was again achieved for both DendrimerA-gB and DendrimerB $+\mathrm{gB} / \mathrm{gH}$, while we observed a lower percentage of inhibition for DendrimerA-gH at $550 \mathrm{nM}$. In panel B, we compared the activities in the same experiment of the two dendrimers: DendrimerA and DendrimerB without peptides. We observed a similar activity for both of them. The insert of panel B shows the activities of the isolated peptides at the concentration present on the dendrimers. The data confirm that the peptides alone are not active at the concentration 
used in the experiments. Thus, the results of the virus pre-treatment experiment clearly indicate that the functionalization of the dendrimers with peptides $\mathrm{gB}$ and $\mathrm{gH}$ is able to induce a significant enhancement of activity.
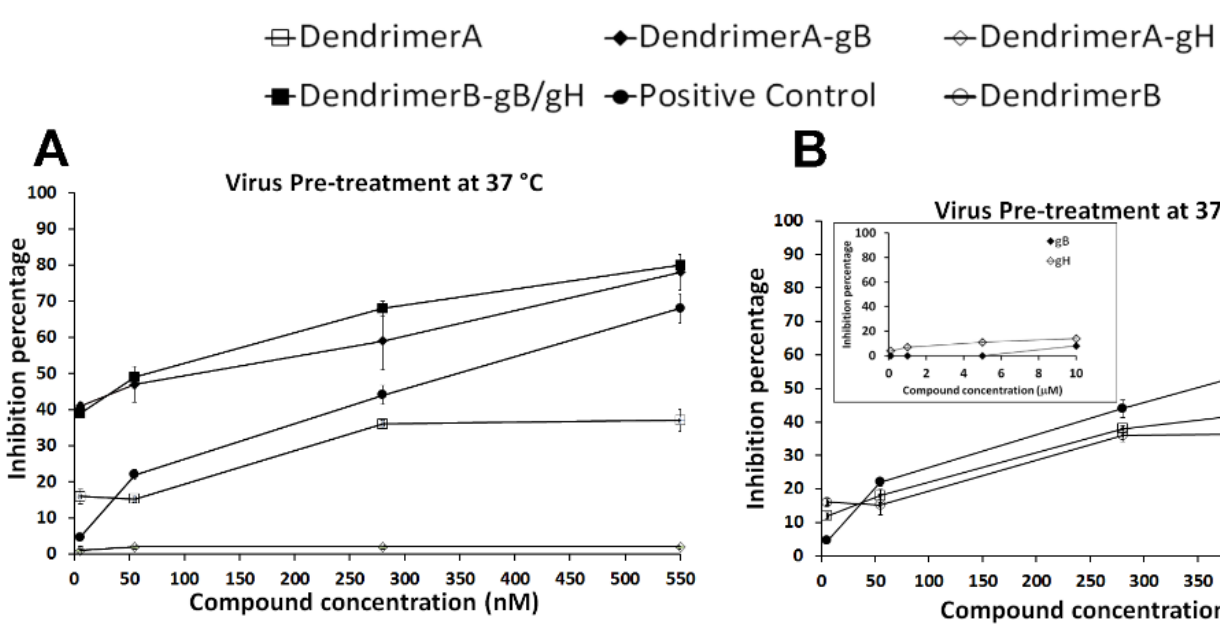

\section{B}
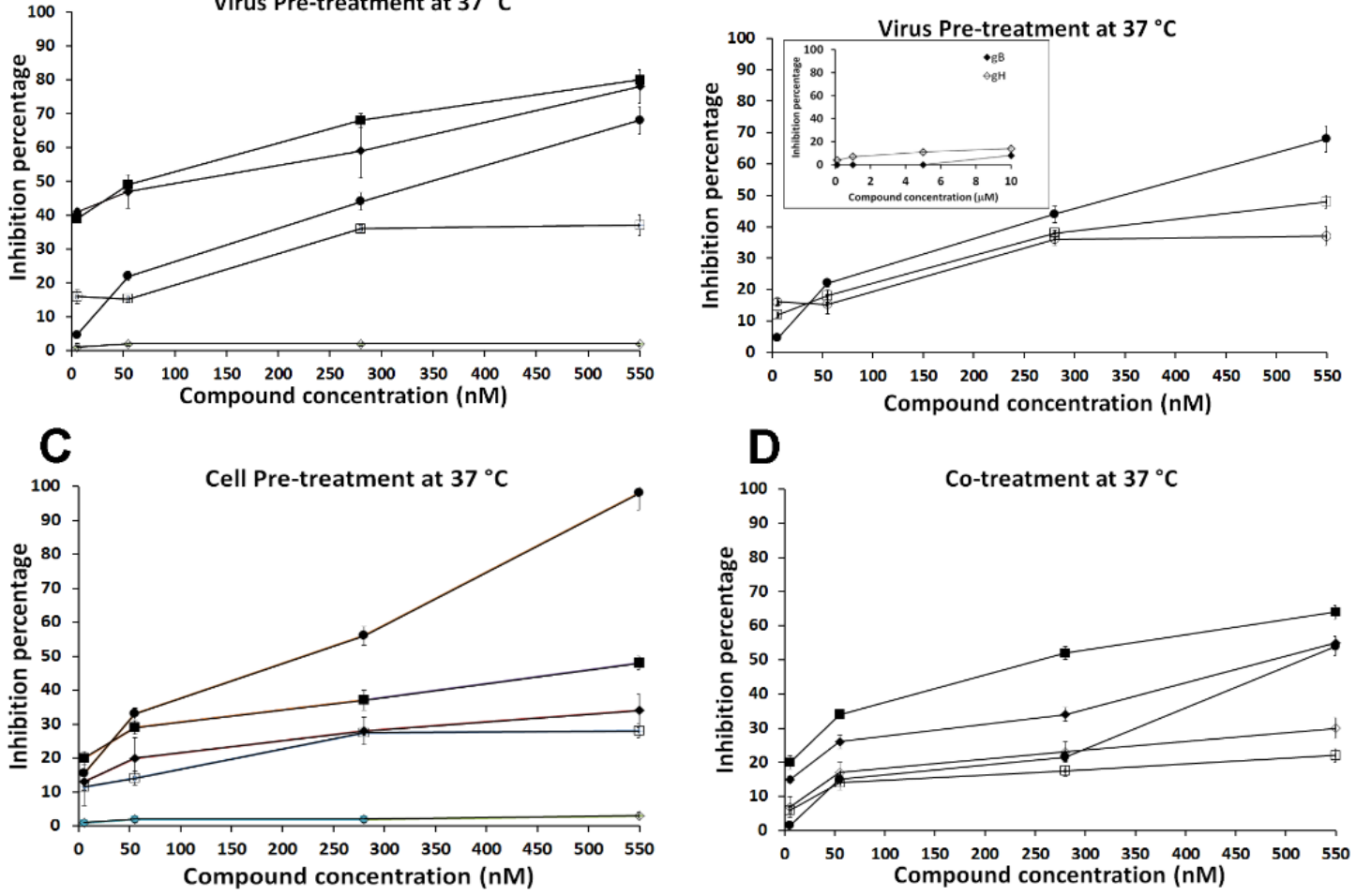

Figure 6. The virus was pre-incubated with compounds for $1 \mathrm{~h}$ at $37^{\circ} \mathrm{C}$ prior to the addition to the cells (Virus PreTreatment, panels A and B). Cells were exposed to compounds either prior to infection (Cell Pre-treatment, panel C) or during attachment and entry (Co-treatment, panel $\mathbf{D}$ ). The control is melittin in virus pre-treatment and co-treatment, and is dextran sulphate in cell pretreatment. Experiments were performed in triplicate, and the percentages of inhibition were calculated with respect to no-compound control experiments. Error bars represent standard deviations.

The possibility to interfere with an early penetration step was further explored. Vero cells were pretreated with the target compounds for $30 \mathrm{~min}$ at $37^{\circ} \mathrm{C}$ before infection. Much lower reduction of infectivity was observed (Figure 6, panel C). In contrast, the dendrimer is retaining its activity. Since the toxicity of the dendrimer is minimal, it is assumed that it may exert an antiviral activity by blocking the cell surface. The lower activity of the peptidodendrimers in this experiment is likely due to the fact that both peptides are involved in the interaction with the virus, as demonstrated by the high inhibition activity showed in the virus pre-treatment experiment.

Since inhibition of HSV penetration is likely the result of a combination obtained by the concerted action of the dendrimer on the cell surface and of the peptides responsible for an interaction with the viral glycoproteins, we performed a co-treatment experiment (Figure 6, panel D). The results obtained from the co-treatment experiment support the key role played by the peptides in regulating the activity of the peptide dendrimer.

The analysis of the obtained results supports the view that, in DendrimerB $+\mathrm{gB} / \mathrm{gH}$, the surface of the dendrimer is covered by the two peptides, thus the activity of the dendrimer may be shielded during the inhibition mechanism in favor of the peptide activities. 


\section{Discussion}

HSV is responsible for many severe diseases and represents a significant challenge to public health due to the rising problem of drug resistance, which is related to overuse of current drugs, as well as to the deficiency in new drug development strategies by the pharmaceutical industry. Hence, the advance in antiviral drug design against HSV infections represents a step forward the global fight against these viruses. Current strategies involving the use of peptides or dendrimers to block viral entry are characterized by the fact that the inhibition concentration is in the micromolar range and likely the interaction is reversible and sensitive to dilutions, which may reduce their usefulness in vivo. In this contribution, we show that it is possible to enhance the mechanism of inhibition by engineering novel antiviral nanotherapeutics which lead to multivalent binding and interactions with the consequent production of irreversible local distortion and loss of infectivity. In particular, we demonstrate that the use of different peptides (i.e., one derived from $\mathrm{gH}$ and the other from $\mathrm{gB}$ ) with different targeting and inhibition mechanisms on multifunctional dendrimers likely determines a deformation of viral particles at much lower concentrations. The existence of several targets on the viral and/or the cell surfaces supports the multivalent binding inhibition strategy. Moreover, dendrimers alone inhibit viral penetration; however, the small size of the molecule, and thus the rigidity of the functional groups, reasonably led to the binding of only a few of the target groups, resulting once again in weak and reversible interactions. In our nanotherapeutics, the peptides perform a key role and, being the surface of the dendrimer covered by them, the activity of the dendrimer is likely shielded during the inhibition mechanism in favor of the peptide activities. Furthermore, the concentration range of activities of the peptides can be significantly reduced when combining them on a dendrimer structure. The idea of selecting different peptides with dissimilar mechanisms of inhibition may also enhance the activity of the nano-compound; the multiple binding to viral particles is useful in trapping and inactivating the virus. We believe that the approach presented here represents a first step towards the development of a novel strategy which has a chance to produce medically relevant drugs to fight many worldwide threatening viral infections. Additionally, in-depth in vitro and in vivo experimentations are necessary to establish whether outstanding inhibitory activity over HSV-1 is confirmed. In any case, it should be highlighted that the approach proposed is fundamentally broad spectrum, supporting the potential prevention and treatment of multiple viral infections simply changing the peptides coupled to the dendrimer, which represents a great advantage when unexpected infections occur.

\section{Materials and Methods}

\subsection{Materials}

All chemicals were purchased from Sigma-Aldrich, Acros Organics, Alfa Aesar, or TCI international, and used as received, unless otherwise noted. Dendrons 1 and 6 were synthesized as previously reported from starting materials purchased from Frontier Scientific. 3-Azidopropylamine was synthesized as previously reported. Dialysis membranes (SpectraPor 6) were purchased from Spectrum Labs and used after rinsing the membrane in water for $30 \mathrm{~min}$. LCMS data were recorded on an Agilent LCMSD Trap XCT spectrometer using electrospray ionization (ESI) and methanol as eluent for starting compounds and acetonitrile ( $0.1 \%$ TFA) for species purified by HPLC. ${ }^{1} \mathrm{HNMR}$ spectra were recorded using a Bruker AV-400, -500, or -600 spectrometer (400.1 MHz, $500.2 \mathrm{MHz}$, or $600.2 \mathrm{MHz}$ ); ${ }^{13} \mathrm{CNMR}$ spectra were recorded on a Bruker AV-600 spectrometer (150.9 MHz). Deuterated solvents were purchased from Cambridge Isotope Laboratories. High-performance liquid chromatography (HPLC) purifications were run on a LC-8A Shimadzu (Kyoto, Japan) system equipped with a SPD-10Avp UV/Vis detector with reverse-phase Jupiter 10u C4 $300 \mathrm{~A}$ column $(10 \times 250 \mathrm{~mm})$ in varying percentages of water and acetonitrile with $0.1 \%$ TFA at a rate of $5 \mathrm{~mL} / \mathrm{min}$. 


\subsection{Synthesis of Monofunctional Dendrimer}

Synthesis of the monofunctional dendrimer scaffold has been reported previously [70]. Briefly, the starting dendron 1 was functionalized at the amino termini with succinic anhydride to achieve the hemisuccinate dendron 2 . The two dendrons are convergently coupled using HATU and Hüngin's base to afford the symmetrical dendrimer 3. After deprotection of the tert-butyl esters, the carboxylic acid groups of dendrimer 4 were subsequently coupled with azidopropylamine to obtain the final monofunctional dendrimer 5, called DendrimerA.

\subsection{Synthesis of the Bifunctional Dendrimer (Janus)}

The synthesis of the Janus-type dendrimer has been reported previously [71]. Briefly, the amino ester dendron 6 was protected at the amine terminus with a 9-fluorenylmethylcarbamate (Fmoc), after which the ester termini were deprotected. Coupling of 3-azidopropylamine and subsequent deprotection of the Fmoc afforded the aminononaazide dendron 9. This was coupled to the hemisuccinate dendron 2 using HATU in the presence of Hüngin's base and deprotected using formic acid to yield the Janus bifunctional dendrimer 11. Dendrimer 11 was purified using preparative HPLC using a water/acetonitrile gradient. The eluted product was monomodal, indicative of its monodispersity. ${ }^{1} \mathrm{H}$ NMR spectroscopic analysis revealed full functionalization, as evidenced by the relative integration of the core protons to the azidopropyl methylene units. The final coupling of dendrimer 11 with allylamine in the presence of HATU and Hüngin's base afforded the target bifunctional dendrimer 12 with functionalized dendrimer faces (DendrimerB). DendrimerB was purified using dialysis (1000 MWCO) against methanol, and characterized using ${ }^{1} \mathrm{H}$ and ${ }^{13} \mathrm{C}$ NMR spectroscopy, as well as MALDI-TOF spectroscopy (see SI) [71].

\subsection{Synthesis of Peptides}

Peptide sequences (Table 1 ) were synthesized on Rink-amide MBHA resin $(0.51 \mathrm{mmol} / \mathrm{g}$ substitution). Syntheses were performed on a $20 \mu \mathrm{mol}$ scale. Fmoc-protected amino acids were coupled using the benzotriazol-1-yl-oxytris(pyrrolidino)phosphonium hexafluorohosphate (PyBOP), hydroxybenzotriazole (HOBt), and diisopropylethylamine (DIPEA) method: 4 eq. amino acid, 4 eq. PyBOP, 4 eq. HOBt, and 8 eq. DIPEA relative to resin loading. The coupling steps were run twice for $20 \mathrm{~min}$ each. The Fmoc group was deprotected with $30 \%$ piperidine in DMF $(v / v)$. Propargyl glycine residue $(\operatorname{PrA})$ was added at the terminus to provide a handle for the copper-catalyzed azide/alkyne cycloaddition reaction (CuAAC) with the terminal azides of the monofunctional dendrimer, and, when necessary, cysteine residue was added at the peptide terminus to provide thiol-ene reaction with alchene groups of Janus bifunctional dendrimer (DendrimerB). Fmoc-PrA-OH was coupled once for 45 min using 2 equivalents each of PyBOP, HOBt, and 4 equivalents of DIPEA.

Fully synthesized peptides were deprotected from the resin with trifluoroacetic acid (TFA) containing 3.8\% $(v / v)$ water, 2.2\% $(v / v)$ anisole, 5.5\% $(v / v)$ thioanisole and ethandithiol (EDT) $3.5 \%(v / v)$ at room temperature and precipitated into ice cold ether. The precipitate was dissolved in water and lyophilized to obtain the crude peptides. Peptides were purified by reverse-phase HPLC with water ( $0.1 \%$ TFA) and acetonitrile $(0.1 \%$ TFA) (from 20 to $80 \%$ over a $20 \mathrm{~min}$ flow of $20 \mathrm{~mL} / \mathrm{min}$ ), as well as checked to exhibit the expected molecular ion on analysis by high-resolution mass spectrometry (HRMS). Pure peptides (higher than 98\%) were achieved in good yields ( $40 \%$ for gB peptide and $50 \%$ for $\mathrm{gH})$.

\subsection{Functionalization of Monofunctional Dendrimer}

The dendrimer ( 1 equivalent) functionalization with PrA-peptide ( $\mathrm{gH}$ and $\mathrm{gB}$ ) (36 equivalents of each peptide) was performed in a water/methanol solution (1:1 $v / v$, about $1 \mathrm{~mL})$ by using 2:4 equivalents (to the azide moiety) of $\mathrm{CuSO}_{4} \cdot 5 \mathrm{H}_{2} \mathrm{O}$ : sodium ascorbate. The reactions were left stirring for $1 \mathrm{~h}$ at $40^{\circ} \mathrm{C}$ and for 2 days at room temperature. The resulting functionalized dendrimers were dialyzed against water/EDTA with 1000 MWCO mem- 
branes overnight, followed by purification by reverse-phase HPLC using a C4 column with water $(0.1 \%$ TFA) and acetonitrile (Acn) $(0.1 \%$ TFA) with a flow rate of $5 \mathrm{~mL} / \mathrm{min}$. Solvent gradients of 30 to $95 \%$ Acn over 20 min for Dendrimer-gH493-511 (DendrimerA-gH) and from 5 to $90 \%$ Acn over 20 min for Dendrimer-gB503-523 (DendrimerA-gB) were used.

After HPLC purification, the peptidodendrimers were passed three times through a $30 \mathrm{KDa}$ (MWCO) ultrafiltration membrane using water:MeOH:DMSO 50/45/5. The functionalization yields were confirmed by $\mathrm{UV}$ analysis $\left(\varepsilon \mathrm{gH}=1189 \mathrm{~m}^{-1} \mathrm{~cm}^{-1}\right.$ at $\left.\lambda=280 \mathrm{~nm}\right)$; $\left(\varepsilon g B=1090 \mathrm{~m}^{-1} \mathrm{~cm}^{-1}\right.$ at $\left.\lambda=280 \mathrm{~nm}\right)$ and compared to the ratio of peptide initially used for the reaction ( $36 \mathrm{~mol}$ peptide per mol dendrimer). From the UV analysis, the peptide functionalization yields were $50 \%$ of the equivalents added.

\subsection{Functionalization of DendrimerB}

The Janus bifunctional dendrimer was functionalized with $\mathrm{gB}$ via copper-catalyzed azide/alkyne cycloaddition and with Cys-gH via photoinduced thiol-ene reaction. In particular, dendrimer (1 eq), Cys-gH (1.5 eq) and DMPA (0.2 eq) in a 4:1 mixture of DMF$\mathrm{H}_{2} \mathrm{O}$ were irradiated with UV light (Spectroline model ENF-240C/FE) while stirring for one hour at $4{ }^{\circ} \mathrm{C}$. After this reaction, gB was coupled to the dendrimer via copper-catalyzed azide/alkyne cycloaddition reaction using the same condition as described above. The Janus bifunctional dendrimer was purified using dialysis (1000 MWCO) against water and characterized using IR spectroscopy.

\subsection{IR Spectroscopy}

The samples were analyzed by FT-IR spectroscopy. The FT-IR spectra were recorded on a UV-Vis spectrophotometer (Jasco, Easton, MD, USA). The characteristic peaks of IR transmission spectra were recorded at a resolution of $4 \mathrm{~cm}^{-1}$ over a wavenumber region of $400-4000 \mathrm{~cm}^{-1}$.

\section{8. Ђ-Potential Measurement}

The $\zeta$-potential of DendrimerB and DendrimerB-gB/gH solutions were measured using Zetasizer Nano-ZS (Malvern Instruments, Worcestershire, UK). All measurements were performed at $25^{\circ} \mathrm{C}$ in water, at $\mathrm{pH} 7$ in triplicate.

\subsection{Circular Dichroism}

CD spectra were recorded from $195 \mathrm{~nm}$ to 260 in a Jasco J-810 spectropolarimeter using a $0.1 \mathrm{~cm}$ quartz cell at room temperature under a constant flow of nitrogen gas. Other experimental settings were: scan speed of $5 \mathrm{~nm} / \mathrm{min}$, sensitivity of $50 \mathrm{mdeg}$, time constant of $16 \mathrm{~s}$, bandwidth of $1 \mathrm{~nm}$. Each spectrum was obtained through averaging three scans; spectra were recorded and corrected for the blank. DendrimerB-gB/gH spectra were recorded in water and in presence of $20 \%$ and $40 \%$ TFE at a concentration of $910^{-5} \mathrm{M}$.

\subsection{Cells and Viruses}

African green monkey kidney cells (Vero) (ATCC CCL-81) were grown in Dulbecco's Modified Eagle Medium (DMEM) supplemented with 10\% fetal bovine serum (FBS), $2 \mathrm{mM}$ L-glutamine and $100 \mathrm{IU} / \mathrm{mL}$ of penicillin-streptomycin in a humidified atmosphere with $5 \% \mathrm{CO}_{2}$ at $37^{\circ} \mathrm{C}$. HSV-1 (strain SC16) carrying a lacZ gene driven by the CMV IE-1 promoter to express $\beta$-galactosidase was propagated on Vero cell monolayers.

\subsection{Antiviral Assays}

Antiviral experiments were executed at different concentrations for all compounds $(0,5.5,55,280$, and $550 \mathrm{nM})$; the concentrations refer to the molecule, thus the peptide concentration corresponds to the quantity present on each dendrimer molecule, i.e., 18 times the concentrations of the monofunctional dendrimer and 9 times for each peptide for the Janus dendrimer. All experiments were done in triplicate. The infectivity inhibition 
percentage was calculated by fixing as $0 \%$ inhibition, the number of plaques obtained in negative controls (only virus).

To determine the effect of functionalized dendrimers on inhibition of HSV infectivity, cell monolayers were treated in different ways:

1. Virus yield reduction assay. Confluent Vero cell monolayers (12-well plates) were washed with phosphate-buffered saline (PBS) and infected with HSV-1 at multiplicity of infection (MOI) of 1 for $1 \mathrm{~h}$ at $37^{\circ} \mathrm{C}$. Then, virus inocula were mixed with the antiviral compounds at the concentrations indicated above. Infected cells were washed with PBS, covered with fresh culture medium, and incubated for $48 \mathrm{~h}$; then, they were scraped into culture medium and disrupted by sonication.

2. Post-treatment assay. $5 \times 10^{5}$ Vero cells (12-well plates) were incubated firstly with virus (MOI 0.01) for $45 \mathrm{~min}$ at $37^{\circ} \mathrm{C}$ and then the compounds were added to the cells followed by an additional incubation period of $30 \mathrm{~min}$ at $37^{\circ} \mathrm{C}$.

3. Co-treatment. In co-exposure experiment, $5 \times 10^{5}$ cells were incubated with peptides and with the viral inoculum at MOI of 0.01 for $45 \mathrm{~min}$ at $37^{\circ} \mathrm{C}$.

4. Cell pretreatment. In cell pre-exposure experiment, $5 \times 10^{5}$ Vero cells were incubated with compounds for $30 \mathrm{~min}$ at $37^{\circ} \mathrm{C}$ and subsequently infected with HSV-1 at MOI of 0.01 for $45 \mathrm{~min}$ at $37^{\circ} \mathrm{C}$.

5. Virus pre-treatment. In virus pre-exposure assay, HSV-1 at MOI of 0.1 was incubated with compounds for $45 \mathrm{~min}$ at $37^{\circ} \mathrm{C}$, and then the mixture was titrated on Vero cell monolayers.

For all treatments, non-penetrated viruses were inactivated by citrate buffer at $\mathrm{pH} 3.0$ after $45 \mathrm{~min}$ incubation with cells at $37^{\circ} \mathrm{C}$. The cells were then incubated for $24 \mathrm{~h}$ at $37^{\circ} \mathrm{C}$ in DMEM supplemented with carboxymethyl cellulose (CMC) $5 \%$. The total virus yield in each well was titrated by plaque assay. Plaques were stained with X-gal and microscopically counted. The mean plaque counts for each concentration were reported as a percentage of the mean plaque count compared to the control virus. The number of plaques was plotted as a function of concentration; concentrations producing $50 \%$ reductions in plaque formation were determined as the $\mathrm{IC}_{50}$.

\subsection{Cytotoxicity}

Vero cells were exposed to increasing concentrations of monofunctional and Janus-type dendrimers functionalized with peptides, and the number of viable cells was determined using the 3-(4,5-dimethylthiazol-2-yl)-2,5-diphenyltetrazolium bromide (MTT) assay [72]. Vero cells were subcultured in 96-well plates at a seeding density of $2 \times 10^{4}$ cells/well and treated with compounds $5.5 \mathrm{nM}, 55 \mathrm{nM}, 0.28 \mu \mathrm{M}, 0.55 \mu \mathrm{M}, 1.1 \mu \mathrm{M}, 2.8 \mu \mathrm{M}$ for 3 and $24 \mathrm{~h}$. The medium was then gently aspirated, MTT solution $(5 \mathrm{mg} / \mathrm{mL})$ was added to each well, and cells were incubated for a further $3 \mathrm{~h}$ at $37^{\circ} \mathrm{C}$. The medium with MTT solution was removed, and the formazan crystals were dissolved with dimethyl sulfoxide. The absorption values were measured at $\lambda_{570}$ using a Bio-Rad Microplate Reader (Bio-Rad Laboratories, Hercules, CA, USA). The viability of Vero cells in each well was reported respect to the control cells (untreated cells).

Author Contributions: Conceptualization, S.G. and M.W.; methodology, A.F., E.A.K. and G.F.; investigation, A.F., V.D.G. and C.Z.; writing-review and editing, S.G. and M.W. All authors have read and agreed to the published version of the manuscript.

Funding: E.A.K. and M.W. thank the National Science Foundation under Grant No. CHE-1902917 for support of this science.

Conflicts of Interest: The authors declare no conflict of interest. 


\section{References}

1. Baloch, S.; Baloch, M.A.; Zheng, T.; Pei, X. The coronavirus disease 2019 (covid-19) pandemic. Tohoku J. Exp. Med. 2020, 250, 271-278. [CrossRef]

2. Kim, E.A.-O.; Lim, E.K.; Park, G.; Park, C.; Lim, J.W.; Lee, H.; Na, W.; Yeom, M.; Kim, J.; Song, D.; et al. Advanced nanomaterials for preparedness against (re-)emerging viral diseases. Adv. Mater. 2021. [CrossRef]

3. Cheng, W.; Yang, C.; Ding, X.; Engler, A.C.; Hedrick, J.L.; Yang, Y.Y. Broad-spectrum antimicrobial/antifouling soft material coatings using poly(ethylenimine) as a tailorable scaffold. Biomacromolecules 2015, 16, 1967-1977. [CrossRef] [PubMed]

4. Lienkamp, K.; Tew, G.N. Synthetic mimics of antimicrobial peptides-A versatile ring-opening metathesis polymerization based platform for the synthesis of selective antibacterial and cell-penetrating polymers. Chem. A Eur. J. 2009, 15, 11784-11800. [CrossRef]

5. Fiore, G.L.; Rowan, S.J.; Weder, C. Optically healable polymers. Chem. Soc. Rev. 2013, 42, 7278-7288. [CrossRef] [PubMed]

6. Korzhikov, V.A.; Gusevskaya, K.V.; Litvinchuk, E.N.; Vlakh, E.G.; Tennikova, T.B. Enzyme-mediated ring-opening polymerization of pentadecalactone to obtain biodegradable polymer for fabrication of scaffolds for bone tissue engineering. Int. J. Polym. Sci. 2013, 2013, 476748. [CrossRef]

7. Weichelt, F.; Frerich, B.; Lenz, S.; Tiede, S.; Buchmeiser, M.R. Ring-opening metathesis polymerization-based synthesis of caco3 nanoparticle-reinforced polymeric monoliths for tissue engineering. Macromol. Rapid Commun. 2010, 31, 1540-1545. [CrossRef] [PubMed]

8. Chang, W.J.; Pan, Y.H.; Tzeng, J.J.; Wu, T.L.; Fong, T.H.; Feng, S.W.; Huang, H.M. Development and testing of x-ray imagingenhanced poly-1-lactide bone screws. PLoS ONE 2015, 10, e0140354. [CrossRef]

9. Goto, K.; Okuzu, Y.; So, K.; Kuroda, Y.; Matsuda, S. Clinical and radiographic evaluation of cemented socket fixation concomitant to acetabular bone grafting fixed with absorbable hydroxyapatite-poly-l-lactide composite screws. J. Orthop. Sci. 2016, $21,57-62$. [CrossRef]

10. Undin, J.; Wistrand, A.F.; Albertsson, A.C. Amorphous and degradable polymers aimed for tissue engineering synthesized by radical ring-opening polymerization. Abstr. Pap. Am. Chem. Soc. 2012, 244.

11. Dove, A.P. Organic catalysis for ring-opening polymerization. ACS Macro Lett. 2012, 1, 1409-1412. [CrossRef]

12. Lopes, M.S.; Jardini, A.L.; Filho, R.M. Synthesis and characterizations of poly (lactic acid) by ring-opening polymerization for biomedical applications. Chem. Eng. Trans. 2014, 38, 331-336.

13. Jung, H.; Carberry, T.P.; Weck, M. Synthesis of first- and second- generation poly(amide)-dendronized polymers via ring-opening metathesis polymerization. Macromolecules 2011, 44, 9075-9083. [CrossRef]

14. Mackenzie, M.C.; Shrivats, A.R.; Konkolewicz, D.; Ayerick, S.E.; McDermott, M.C.; Hollinger, J.O.; Matyjaszewski, K. Synthesis of poly(meth)acrylates with thioether and tertiary sulfonium groups by arget atrp and their use as sirna delivery agents Biomacromolecules 2015, 16, 236-245. [CrossRef] [PubMed]

15. Williams, V.A.; Matyjaszewski, K. Expanding the atrp toolbox: Methacrylate polymerization with an elemental silver reducing agent. Macromolecules 2015, 48, 6457-6464. [CrossRef]

16. Chmielarz, P.; Park, S.; Sobkowiak, A.; Matyjaszewski, K. Synthesis of beta-cyclodextrin-based star polymers via a simplified electrochemically mediated atrp. Polymer 2016, 88, 36-42. [CrossRef]

17. Iacono, M.; Heise, A. Stable poly(methacrylic acid) brush decorated silica nano-particles by arget atrp for bioconjugation. Polymers 2015, 7, 1427-1443. [CrossRef]

18. Colzani, B.; Biagiotti, M.; Speranza, G.; Dorati, R.; Modena, T.; Conti, B.; Tomasi, C.; Genta, I. Smart biodegradable nanoparticulate materials: Poly-lactide-co-glycolide functionalization with selected peptides. Curr. Nanosci. 2016, 12, 347-356. [CrossRef]

19. Kulkarni, A.; Lele, A.; Sivaram, S.; Rajamohanan, P.R.; Velankar, S.; Chatterji, A. Star telechelic poly(l-lactide) ionomers. Macromolecules 2015, 48, 6580-6588. [CrossRef]

20. Noga, D.E.; Petrie, T.; Kumar, A.; Weck, M.; García, A.J.; Collard, D.M. Synthesis and modification of functional poly(lactide) copolymers: Towards biofunctional materials. Biomacromolecules 2008, 9, 2056-2062. [CrossRef] [PubMed]

21. Yao, L.; Oquendo, L.E.; Schulze, M.W.; Lewis, R.M.; Gladfelter, W.L.; Hillmyer, M.A. Poly(cyclohexylethylene)-block-poly(lactide) oligomers for ultrasmall nanopatterning using atomic layer deposition. ACS Appl. Mater. Inter. 2016, 8, 7431-7439. [CrossRef] [PubMed]

22. Isono, T.; Kondo, Y.; Ozawa, S.; Chen, Y.G.; Sakai, R.; Sato, S.; Tajima, K.; Kakuchi, T.; Satoh, T. Stereoblock-like brush copolymers consisting of poly(l-lactide) and poly(d-lactide) side chains along poly(norbornene) backbone: Synthesis, stereocomplex formation, and structure-property relationship. Macromolecules 2014, 47, 7118-7128. [CrossRef]

23. Nystrom, A.; Malkoch, M.; Furo, I.; Nystrom, D.; Unal, K.; Antoni, P.; Vamvounis, G.; Hawker, C.J.; Wooley, K.; Malmstrom, E.; et al. Characterization of poly(norbornene) dendronized polymers prepared by ring-opening metathesis polymerization of dendron bearing monomers. Macromolecules 2006, 39, 7241-7249. [CrossRef]

24. de Miguel, L.; Noiray, M.; Surpateanu, G.; Iorga, B.I.; Ponchel, G. Poly(gamma-benzyl-l-glutamate)-peg-alendronate multivalent nanoparticles for bone targeting. Int. J.Pharm. 2014, 460, 73-82. [CrossRef] [PubMed]

25. Qian, J.; Yong, X.; Xu, W.; Jin, X. Preparation and characterization of bimodal porous poly(gamma-benzyl-1-glutamate) scaffolds for bone tissue engineering. Mater. Sci. Eng. C Mater. Biol. Appl. 2013, 33, 4587-4593. [CrossRef] 
26. Upadhyay, K.K.; Bhatt, A.N.; Mishra, A.K.; Dwarakanath, B.S.; Jain, S.; Schatz, C.; Le Meins, J.-F.; Farooque, A.; Chandraiah, G.; Jain, A.K.; et al. The intracellular drug delivery and anti tumor activity of doxorubicin loaded poly( $\gamma$-benzyl l-glutamate)-bhyaluronan polymersomes. Biomaterials 2010, 31, 2882-2892. [CrossRef]

27. Borchmann, D.E.; Tarallo, R.; Avendano, S.; Falanga, A.; Carberry, T.P.; Galdiero, S.; Weck, M. Membranotropic peptidefunctionalized poly(lactide)-graft-poly(ethylene glycol) brush copolymers for intracellular delivery. Macromolecules 2015, 48, 942-949. [CrossRef]

28. Lorenzo, M.M.; Decker, C.G.; Kahveci, M.U.; Paluck, S.J.; Maynard, H.D. Homodimeric protein-polymer conjugates via the tetrazine-trans-cyclooctene ligation. Macromolecules 2016, 49, 30-37. [CrossRef]

29. Basak, S.; Punetha, V.D.; Bisht, G.; Bisht, S.S.; Sahoo, N.G.; Cho, J.W. Recent trends of polymer-protein conjugate application in biocatalysis: A review. Polym. Rev. 2015, 55, 163-198. [CrossRef]

30. Borchmann, D.E.; Carberry, T.P.; Weck, M. "Bio"-macromolecules: Polymer-protein conjugates as emerging scaffolds for therapeutics. Macromol. Rapid Commun. 2014, 35, 27-43. [CrossRef]

31. Heredia, K.L.; Tao, L.; Grover, G.N.; Maynard, H.D. Heterotelechelic polymers for capture and release of protein-polymer conjugates. Polym. Chem. UK 2010, 1, 168-170. [CrossRef]

32. Gauthier, M.A.; Klok, H.A. Peptide/protein-polymer conjugates: Synthetic strategies and design concepts. Chem. Commun. 2008, 2591-2611. [CrossRef]

33. Shimoboji, T.; Ding, Z.L.; Stayton, P.S.; Hoffman, A.S. Photoswitching of ligand association with a photoresponsive polymerprotein conjugate. Bioconjug. Chem. 2002, 13, 915-919. [CrossRef]

34. Liu, Q.M.; Chen, S.; Chen, J.; Du, J.Z. An asymmetrical polymer vesicle strategy for significantly improving t-1 mri sensitivity and cancer-targeted drug delivery. Macromolecules 2015, 48, 739-749. [CrossRef]

35. Liu, Z.Y.; Dong, C.H.; Wang, X.M.; Wang, H.J.; Li, W.; Tan, J.; Chang, J. Self-assembled biodegradable protein-polymer vesicle as a tumor-targeted nanocarrier. ACS Appl. Mater. Interfaces 2014, 6, 2393-2400. [CrossRef]

36. Srinivas, G.; Mohan, R.V.; Kelkar, A.D. Polymer micelle assisted transport and delivery of model hydrophilic components inside a biological lipid vesicle: A coarse-grain simulation study. J. Phys. Chem. B 2013, 117, 12095-12104. [CrossRef]

37. Zhu, H.S.; Geng, Q.R.; Chen, W.Q.; Zhu, Y.Q.; Chen, J.; Du, J.Z. Antibacterial high-genus polymer vesicle as an "armed" drug carrier. J. Mater. Chem. B 2013, 1, 5496-5504. [CrossRef] [PubMed]

38. Brownlie, A.; Uchegbu, I.F.; Schatzlein, A.G. Pei-based vesicle-polymer hybrid gene delivery system with improved biocompatibility. Int. J. Pharm. 2004, 274, 41-52. [CrossRef] [PubMed]

39. Nicolas, J. Drug-initiated synthesis of polymer prodrugs: Combining simplicity and efficacy in drug delivery. Chem. Mater. 2016, 28, 1591-1606. [CrossRef]

40. Bai, Y.; Xing, H.; Vincil, G.A.; Lee, J.; Henderson, E.J.; Lu, Y.; Lemcoff, N.G.; Zimmerman, S.C. Practical synthesis of water-soluble organic nanoparticles with a single reactive group and a functional carrier scaffold. Chem. Sci. 2014, 5, 2862-2868. [CrossRef]

41. Issberner, J.; Moors, R.; Vögtle, F. Dendrimers: From generations and functional groups to functions. Angew. Chem. Int. Ed. Engl. 1995, 33, 2413-2420. [CrossRef]

42. Tomalia, D.; Baker, H.; Dewald, J.; Hall, M.; Kallos, G.; Martin, S.; Roeck, J.; Ryder, J.; Smith, P. A new class of polymers: Starburst-dendritic macromolecules. Polym. J. 1985, 17, 117-132. [CrossRef]

43. Newkome, G.R.; Yao, Z.; Baker, G.R.; Gupta, V.K. Micelles. Part 1. Cascade molecules: A new approach to micelles. A [27]-arborol. J. Org. Chem. 1985, 50, 2003-2004. [CrossRef]

44. Hawker, C.; Fréchet, J.M. A new convergent approach to monodisperse dendritic macromolecules. J. Chem. Soc. Chem. Commun. 1990, 1010-1013. [CrossRef]

45. Hawker, C.J.; Frechet, J.M. Preparation of polymers with controlled molecular architecture. A new convergent approach to dendritic macromolecules. J. Am. Chem. Soc. 1990, 112, 7638-7647. [CrossRef]

46. Cheng, Y.; Man, N.; Xu, T.; Fu, R.; Wang, X.; Wang, X.; Wen, L. Transdermal delivery of nonsteroidal anti-inflammatory drugs mediated by polyamidoamine (pamam) dendrimers. J. Pharm. Sci. 2007, 96, 595-602.

47. Fu, H.L.; Cheng, S.X.; Zhang, X.Z.; Zhuo, R.X. Dendrimer/DNA complexes encapsulated functional biodegradable polymer for substrate-mediated gene delivery. J. Gene Med. 2008, 10, 1334-1342. [CrossRef] [PubMed]

48. Patel, H.; Patel, P. Dendrimer applications-A review. Int. J. Pharm. Bio Sci. 2013, 4, 454-463.

49. Ardestani, M.S.; Fordoei, A.S.; Abdoli, A.; Ahangari Cohan, R.; Bahramali, G.; Sadat, S.M.; Siadat, S.D.; Moloudian, H.; Nassiri Koopaei, N.; Bolhasani, A.; et al. Nanosilver based anionic linear globular dendrimer with a special significant antiretroviral activity. J. Mater. Sci. Mater. Med. 2015, 26, 179. [CrossRef] [PubMed]

50. Worley, B.V.; Schilly, K.M.; Schoenfisch, M.H. Anti-biofilm efficacy of dual-action nitric oxide-releasing alkyl chain modified poly(amidoamine) dendrimers. Mol. Pharm. 2015, 12, 1573-1583. [CrossRef] [PubMed]

51. Astruc, D.; Boisselier, E.; Ornelas, C. Dendrimers designed for functions: From physical, photophysical, and supramolecular properties to applications in sensing, catalysis, molecular electronics, photonics, and nanomedicine. Chem. Rev. 2010, 110, 1857-1959. [CrossRef] [PubMed]

52. De Gennes, P.G.; Hervet, H. Statistics of « starburst » polymers. J. Physique Lett. 1983, 44, 351-360. [CrossRef]

53. Nourse, A.; Millar, D.B.; Minton, A.P. Physicochemical characterization of generation 5 polyamidoamine dendrimers. Biopolymers 2000, 53, 316-328. [CrossRef] 
54. Kaminskas, L.M.; McLeod, V.M.; Porter, C.J.; Boyd, B.J. Association of chemotherapeutic drugs with dendrimer nanocarriers: An assessment of the merits of covalent conjugation compared to noncovalent encapsulation. Mol. Pharm. 2012, 9, 355-373. [CrossRef] [PubMed]

55. Kimberlin, D.W.; Whitley, R.J. Antiviral therapy of hsv-1 and -2. In Human Herpesviruses: Biology, Therapy, and Immunoprophylaxis; Arvin, A., Campadelli-Fiume, G., Mocarski, E., Moore, P.S., Roizman, B., Whitley, R., Yamanishi, K., Eds.; Cambridge University Press: Cambridge, UK, 2007.

56. Englund, J.A.; Zimmerman, M.E.; Swierkosz, E.M.; Goodman, J.L.; Scholl, D.R.; Balfour, H.H., Jr. Herpes simplex virus resistant to acyclovir. A study in a tertiary care center. Ann. Intern. Med. 1990, 112, 416-422. [CrossRef]

57. Clementi, N.; Criscuolo, E.; Cappelletti, F.; Burioni, R.; Clementi, M.; Mancini, N. Novel therapeutic investigational strategies to treat severe and disseminated hsv infections suggested by a deeper understanding of in vitro virus entry processes. Drug Discov. Today 2016, 21, 682-691. [CrossRef]

58. Xie, D.; Yao, C.; Wang, L.; Min, W.; Xu, J.; Xiao, J.; Huang, M.; Chen, B.; Liu, B.; Li, X. An albumin-conjugated peptide exhibits potent anti-hiv activity and long in vivo half-life. Antimicrob. Agents Chemother. 2010, 54, 191-196. [CrossRef] [PubMed]

59. Connolly, S.A.; Jackson, J.O.; Jardetzky, T.S.; Longnecker, R. Fusing structure and function: A structural view of the herpesvirus entry machinery. Nat. Rev. Microbiol. 2011, 9, 369-381. [CrossRef]

60. Galdiero, S.; Falanga, A.; Tarallo, R.; Russo, L.; Galdiero, E.; Cantisani, M.; Morelli, G.; Galdiero, M. Peptide inhibitors against herpes simplex virus infections. J. Pept. Sci. 2013, 19, 148-158. [CrossRef]

61. Falanga, A.; Tarallo, R.; Vitiello, G.; Vitiello, M.; Perillo, E.; Cantisani, M.; D’Errico, G.; Galdiero, M.; Galdiero, S. Biophysical characterization and membrane interaction of the two fusion loops of glycoprotein $\mathrm{b}$ from herpes simplex type i virus. PLoS ONE 2012, 7, e32186. [CrossRef]

62. Cantisani, M.; Falanga, A.; Incoronato, N.; Russo, L.; De Simone, A.; Morelli, G.; Berisio, R.; Galdiero, M.; Galdiero, S. Conformational modifications of $\mathrm{gb}$ from herpes simplex virus type 1 analyzed by synthetic peptides. J. Med. Chem. 2013, 56, 8366-8376. [CrossRef]

63. Franci, G.; Falanga, A.; Zannella, C.; Folliero, V.; Martora, F.; Galdiero, M.; Galdiero, S.; Morelli, G. Infectivity inhibition by overlapping synthetic peptides derived from the gh/gl heterodimer of herpes simplex virus type 1. J. Pept. Sci. 2017, 23, 311-319. [CrossRef] [PubMed]

64. Tarallo, R.; Carberry, T.P.; Falanga, A.; Vitiello, M.; Galdiero, S.; Galdiero, M.; Weck, M. Dendrimers functionalized with membrane-interacting peptides for viral inhibition. Int. J. Nanomed. 2013, 8, 521-534.

65. Galdiero, S.; Falanga, A.; Vitiello, M.; D’Isanto, M.; Cantisani, M.; Kampanaraki, A.; Benedetti, E.; Browne, H.; Galdiero, M. Peptides containing membrane-interacting motifs inhibit herpes simplex virus type 1 infectivity. Peptides 2008, 29, $1461-1471$. [CrossRef]

66. Galdiero, S.; Falanga, A.; Vitiello, M.; D’Isanto, M.; Collins, C.; Orrei, V.; Browne, H.; Pedone, C.; Galdiero, M. Evidence for a role of the membrane-proximal region of herpes simplex virus type 1 glycoprotein $\mathrm{h}$ in membrane fusion and virus inhibition. Chembiochem 2007, 8, 885-895. [CrossRef]

67. Galdiero, S.; Vitiello, M.; D’Isanto, M.; Falanga, A.; Collins, C.; Raieta, K.; Pedone, C.; Browne, H.; Galdiero, M. Analysis of synthetic peptides from heptad-repeat domains of herpes simplex virus type 1 glycoproteins h and b. J. Gen. Virol. 2006, 87, 1085-1097. [CrossRef] [PubMed]

68. Lombardi, L.; Falanga, A.; Del Genio, V.; Palomba, L.; Galdiero, M.; Franci, G.; Galdiero, S. A boost to the antiviral activity: Cholesterol tagged peptides derived from glycoprotein b of herpes simplex virus type i. Int. J. Biol. Macromol. 2020, 162, 882-893. [CrossRef] [PubMed]

69. Cagno, V.; Andreozzi, P.; D’Alicarnasso, M.; Jacob Silva, P.; Mueller, M.; Galloux, M.; Le Goffic, R.; Jones, S.T.; Vallino, M.; Hodek, J.; et al. Broad-spectrum non-toxic antiviral nanoparticles with a virucidal inhibition mechanism. Nat. Mater. 2017, 17, 195. [CrossRef]

70. Carberry, T.P.; Tarallo, R.; Falanga, A.; Finamore, E.; Galdiero, M.; Weck, M.; Galdiero, S. Dendrimer functionalization with a membrane-interacting domain of herpes simplex virus type 1: Towards intracellular delivery. Chem. A Eur. J. 2012, 18, 13678-13685. [CrossRef] [PubMed]

71. Kaufman, E.A.; Tarallo, R.; Elacqua, E.; Carberry, T.P.; Weck, M. Synthesis of well-defined bifunctional newkome-type dendrimers. Macromolecules 2017, 50, 4897-4905. [CrossRef]

72. Kumar, P.; Nagarajan, A.; Uchil, P.D. Analysis of cell viability by the mtt assay. Cold Spring Harb. Protoc. 2018, 2018, pdb-prot095505. [CrossRef] 